\title{
Metal Complex Formation in Melts of Acetamide-Ammonium Nitrate-Water Mixtures, Part I. Cobalt(II) Chloride Complexes
}

\author{
István J. Zsigrai, Slobodan B. Gadžurić, and Borko Matijević \\ Department of Chemistry, Faculty of Science, University of Novi Sad, Trg D. Obradovića 3, \\ 21000 Novi Sad, Serbia and Montenegro
}

Reprint requests to Dr. I. Z.; Fax: +381 21454 065; E-mail: zigrai@ih.ns.ac.yu

Z. Naturforsch. 60a, 201 - 206 (2005); received November 19, 2004

\begin{abstract}
The complex formation between cobalt(II) and chloride ions in molten $\mathrm{NH}_{4} \mathrm{NO}_{3} \cdot 2 \cdot 61 \mathrm{H}_{2} \mathrm{O}$, $\mathrm{NH}_{4} \mathrm{NO}_{3} \cdot \mathrm{CH}_{3} \mathrm{CONH}_{2} \cdot 1.61 \mathrm{H}_{2} \mathrm{O}$ and $\mathrm{NH}_{4} \mathrm{NO}_{3} \cdot 2.61 \mathrm{CH}_{3} \mathrm{CONH}_{2}$ has been investigated. Absorption spectra of cobalt(II) chloride containing variable amounts of ammonium chloride were recorded at 45 to $60^{\circ} \mathrm{C}$. In the absence of chloride, the solutions show spectra typical for octahedral co-ordination of cobalt(II). Addition of chloride caused a shift of the absorption maximum toward lower energies and an increase of the molar absorption coefficient with increasing chloride concentration. The position of the absorption maximum and the intensity of the absorption indicate tetrahedral or severely distorted octahedral co-ordination. The stability constants for $\left[\mathrm{Co}\left(\mathrm{NO}_{3}\right)_{4}\right]^{2-},\left[\mathrm{Co}\left(\mathrm{NO}_{3}\right)_{2} \mathrm{Cl}_{2}\right]^{2-}$ and $\left[\mathrm{CoCl}_{4}\right]^{2-}$ complex formation in $\mathrm{NH}_{4} \mathrm{NO}_{3} \cdot 2 \cdot 61 \mathrm{CH}_{3} \mathrm{CONH}_{2}$ are reported.
\end{abstract}

Key words: Cobalt(II) Chloride Complexes; Acetamide; Ammonium Nitrate; Stability Constants.

\section{Introduction}

Studies on ionic association (complex formation) in highly concentrated electrolyte solutions have mainly been restricted to inorganic salts and most concentrated aqueous solutions (so-called hydrous melts) as reaction media. Recently, attention has been paid to concentrated solutions of inorganic salts in organic solvents, e.g. dimethyl sulphoxide [1], and to melts consisting of an inorganic salt and an organic component such as acetamide [2-4]. Due to some physical properties of acetamide resembling water (e.g. relative permittivity, density and auto dissociation constant), mixtures of inorganic salts with acetamide and hydrous melts in which water is partially replaced by acetamide are particularly interesting. Acetamide and its mixtures with inorganic salts have high latent heats of fusion [5]. They have been considered as phase change materials for thermal energy storage [6-8]. Studies of acetamide and acetamide-halide salt solutions have attracted attention due to their possible application as cell electrolytes for thermal batteries $[9,10]$. The stepwise formation of cobalt(II) chloride complexes in molten acetamide and in acetamide-calcium nitrate tetrahydrate melts has also been studied [2,11].

In the present study absorption spectra of cobalt(II) chloride in ammonium nitrate-acetamide, ammo- nium nitrate-water and ammonium nitrate-acetamide-water systems of the composition $\mathrm{NH}_{4} \mathrm{NO}_{3}$ $\cdot 2.61 \mathrm{CH}_{3} \mathrm{CONH}_{2}, \mathrm{NH}_{4} \mathrm{NO}_{3} \cdot 2.61 \mathrm{H}_{2} \mathrm{O}$ and $\mathrm{NH}_{4} \mathrm{NO}_{3}$. $\mathrm{CH}_{3} \mathrm{CONH}_{2} \cdot 1.61 \mathrm{H}_{2} \mathrm{O}$, respectively, have been investigated. These melts contain several potential ligands (i.e. $\mathrm{CH}_{3} \mathrm{CONH}_{2}, \mathrm{H}_{2} \mathrm{O}$ and $\mathrm{NO}_{3}^{-}$), which can compete among themselves and with the chloride ligand for sites in the co-ordination sphere of cobalt(II). Therefore numerous simultaneous complex formation equilibria should be expected, especially in the case of $\mathrm{NH}_{4} \mathrm{NO}_{3} \cdot \mathrm{CH}_{3} \mathrm{CONH}_{2} \cdot 1.61 \mathrm{H}_{2} \mathrm{O}$. Ammonium nitrateacetamide melts at about $40{ }^{\circ} \mathrm{C}$, while the other two systems are liquid above $30{ }^{\circ} \mathrm{C}$. Hence, the apparatus and technique commonly used for aqueous solutions can be applied.

\section{Experimental}

All commercial chemicals used were reagent grade products. Acetamide was recrystallized from benzene + ethyl acetate $(10+3)$, washed with ether + ethanol $(9+1)$ and dried at $60{ }^{\circ} \mathrm{C}$. The other chemicals where used without further purification. Ammonium nitrate and ammonium chloride were dried at $80{ }^{\circ} \mathrm{C}$. Anhydrous cobalt(II) chloride was obtained from hexahydrate by gradual heating up to $110{ }^{\circ} \mathrm{C}$. The solvent melts were prepared by melting together 
Table 1. The composition of the melts, the spectra of which are presented in Figures 1-3.

\begin{tabular}{lllllll}
\hline \multicolumn{3}{c}{ Figure 1 } & \multicolumn{2}{c}{ Figure 2 } & \multicolumn{2}{c}{ Figure 3 } \\
\hline No. & $\begin{array}{l}c\left(\mathrm{Co}^{2+}\right) / \\
\mathrm{mol} \mathrm{dm}^{-3}\end{array}$ & $\begin{array}{l}c\left(\mathrm{Cl}^{-}\right) / \\
\mathrm{mol} \mathrm{dm}^{-3}\end{array}$ & $\begin{array}{l}c\left(\mathrm{Co}^{2+}\right) / \\
\mathrm{mol} \mathrm{dm}^{-3}\end{array}$ & $\begin{array}{l}c\left(\mathrm{Cl}^{-}\right) / \\
\mathrm{mol} \mathrm{dm}^{-3}\end{array}$ & $\begin{array}{l}c\left(\mathrm{Co}^{2+}\right) / \\
\mathrm{mol} \mathrm{dm}^{-3}\end{array}$ & $\begin{array}{l}c\left(\mathrm{Cl}^{-}\right) / \\
\mathrm{mol} \mathrm{dm}^{-3}\end{array}$ \\
\hline 1 & 0.05065 & 0.0000 & 0.05589 & 0.0000 & 0.03103 & 0.06206 \\
2 & 0.00806 & 1.4697 & 0.01201 & 0.6220 & 0.014308 & 0.5640 \\
3 & 0.01989 & 2.0973 & 0.004983 & 0.9060 & 0.003612 & 0.2626 \\
4 & 0.01060 & 2.3075 & 0.004510 & 1.1425 & 0.003790 & 0.3222 \\
5 & 0.02393 & 2.6002 & 0.009590 & 1.2628 & 0.004254 & 0.3877 \\
6 & 0.02670 & 2.7842 & 0.008989 & 1.2809 & 0.002703 & 0.4350 \\
7 & 0.02757 & 2.8481 & 0.007508 & 1.3986 & 0.002467 & 0.5537 \\
8 & 0.02872 & 3.1293 & 0.008292 & 1.4355 & 0.002319 & 0.5801 \\
9 & 0.03203 & 3.3427 & 0.008525 & 1.5717 & 0.001448 & 0.6364 \\
\hline
\end{tabular}

appropriate amounts of ammonium nitrate, acetamide and/or water at about $60{ }^{\circ} \mathrm{C}$ in stoppered glass vessels. Stock solutions of cobalt(II) in each of the solvent melts were prepared. Cobalt(II) nitrate hexahydrate was used as a source of cobalt(II) in hydrous melts, and dehydrated cobalt(II) chloride in anhydrous $\mathrm{NH}_{4} \mathrm{NO}_{3} \cdot 2.61 \mathrm{CH}_{3} \mathrm{CONH}_{2}$ melt. Weighed amounts of the stock solution and anhydrous $\mathrm{NH}_{4} \mathrm{Cl}$ were added to each solvent melt to obtain solutions of desired cobalt(II) and chloride concentrations. The concentrations were converted to molarities $\left(\mathrm{mol} \mathrm{dm}^{-3}\right)$, so that molar absorption coefficients could be calculated. The density $d$ of the melts, required for conversion of molality units into molarities, was determined picnometrically at different temperatures. The dependence of the melt density on temperature in the range $40-70{ }^{\circ} \mathrm{C}$ can be given by the equations

$$
\begin{aligned}
& d / \mathrm{g} \mathrm{cm}^{-3}=1.201-1.52 \cdot 10^{-4} T \\
& \quad \text { for } \mathrm{NH}_{4} \mathrm{NO}_{3} \cdot 2.61 \mathrm{CH}_{3} \mathrm{CONH}_{2}, \\
& d / \mathrm{g} \mathrm{cm}^{-3}=1.384-5.55 \cdot 10^{-4} T \\
& \quad \text { for } \mathrm{NH}_{4} \mathrm{NO}_{3} \cdot \mathrm{CH}_{3} \mathrm{CONH}_{2} \cdot 1.61 \mathrm{H}_{2} \mathrm{O}, \\
& d / \mathrm{g} \mathrm{cm}^{-3}=1.484-6.43 \cdot 10^{-4} T \\
& \quad \text { for } \mathrm{NH}_{4} \mathrm{NO}_{3} \cdot 2.61 \mathrm{H}_{2} \mathrm{O},
\end{aligned}
$$

where $T$ is the absolute temperature.

The absorption spectra of the melts with variable chloride concentration were recorded in the wavelength range $400-800 \mathrm{~nm}$ on a Secomam Anthelie Advanced 2 or on a Hewlett Packard 8452A Diode Array spectrophotometer with thermostated cell compartments. The temperature was kept constant to $\pm 0.5{ }^{\circ} \mathrm{C}$. Rectangular quartz or glass spectrophotometric cells of $10 \mathrm{~mm}$ path length with Teflon stoppers were used. The reference cells were filled with solvent melts containing appropriate concentrations of ammonium chloride.

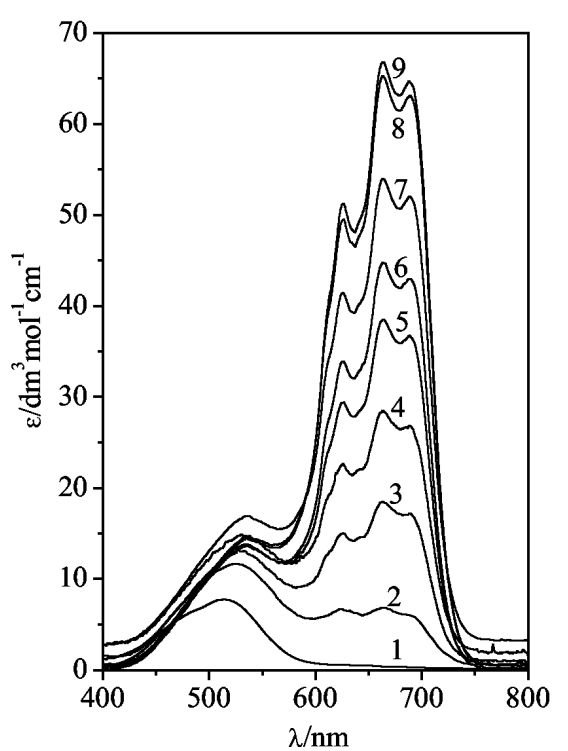

Fig. 1. Variation of the spectra of cobalt(II) in $\mathrm{NH}_{4}$ $\mathrm{NO}_{3} \cdot 2.61 \mathrm{H}_{2} \mathrm{O}$ with the chloride concentration at $60{ }^{\circ} \mathrm{C}$. The corresponding melt compositions are given in Table 1.

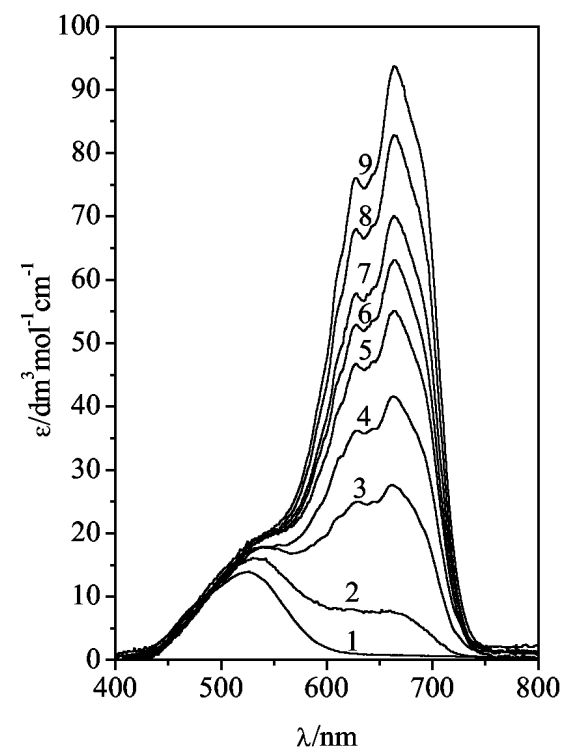

Fig. 2. Variation of the spectra of cobalt(II) in $\mathrm{NH}_{4}$ $\mathrm{NO}_{3} \cdot \mathrm{CH}_{3} \mathrm{CONH}_{2} \cdot 1.61 \mathrm{H}_{2} \mathrm{O}$ with the chloride concentration at $60{ }^{\circ} \mathrm{C}$. The corresponding melt compositions are given in Table 1.

For each solvent a series of cobalt concentrations with increasing chloride ratio was studied at different temperatures. Representative spectra at different cobalt(II) and chloride concentrations covering the whole range studied are given in Figures $1-3$. The compositions of the solutions corresponding to the spectra are given in 


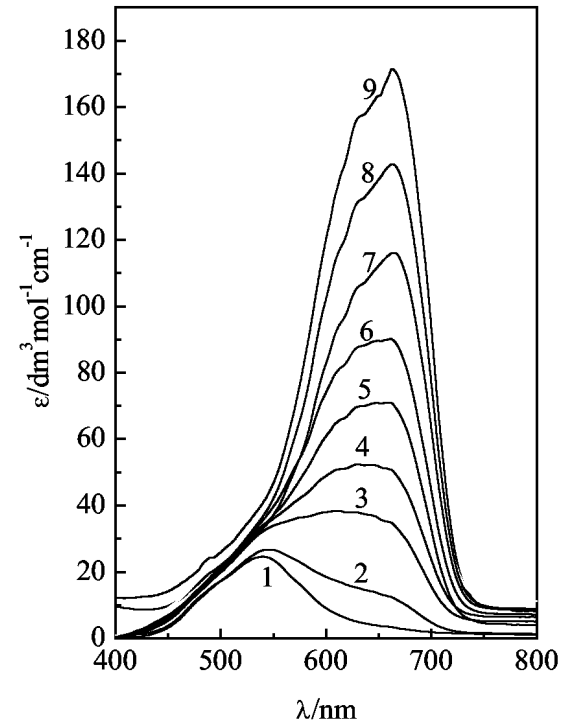

Fig. 3. Variation of the spectra of cobalt(II) in $\mathrm{NH}_{4}$ $\mathrm{NO}_{3} \cdot 2.61 \mathrm{CH}_{3} \mathrm{CONH}_{2}$ with the chloride concentration at $60{ }^{\circ} \mathrm{C}$. The corresponding melt compositions are given in Table 1 .

Table 1. The complete experimental results can be obtained upon request from the authors.

\section{Results and Discussion}

\subsection{The Absorption Spectra}

The spectrum of cobalt(II) nitrate solution in $\mathrm{NH}_{4}$ $\mathrm{NO}_{3} \cdot 2.61 \mathrm{H}_{2} \mathrm{O}$, Fig. 1, shows an absorption maximum at $514 \mathrm{~nm}$, very close to $510 \mathrm{~nm}$, ascribed to octahedral hexa-co-ordinated cobalt(II) aqua-complexes in aqueous solutions [11]. In $\mathrm{NH}_{4} \mathrm{NO}_{3} \cdot \mathrm{CH}_{3} \mathrm{CONH}_{2} \cdot 1.61 \mathrm{H}_{2} \mathrm{O}$ and in $\mathrm{NH}_{4} \mathrm{NO}_{3} \cdot 2.61 \mathrm{CH}_{3} \mathrm{CONH}_{2}$ (Figs. 2 and 3 ) the absorption maximum appeared at 522 and $538 \mathrm{~nm}$, respectively. These values are between the $510 \mathrm{~nm}$ in aqueous solutions and $550 \mathrm{~nm}$ in $(\mathrm{K}, \mathrm{Li}) \mathrm{NO}_{3}$ eutectic $[12,13]$. In Figs. $1-3$ the overall molar absorption coefficient, defined as

$$
\varepsilon=A l^{-1} c_{M}^{-1}
$$

where $A$ is the absorbance, $l$ the light pathway and $c_{\mathrm{M}}$ the total cobalt(II) concentration, is plotted against wavelengths. The position of the maximum and the value of the overall molar absorption coefficient indicate octahedral or dodecahedral co-ordination of cobalt, as suggested earlier [11,14-17]. The absorption intensity increases with temperature, as expected for octahedral co-ordination.

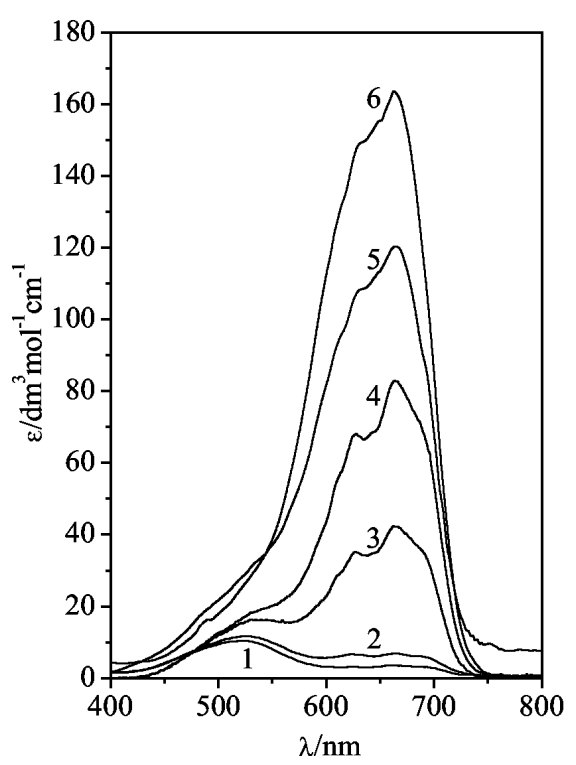

Fig. 4. Variation of spectra with temperature. Curves: $(1,2) 0.007004 \mathrm{~mol} \mathrm{~kg}^{-1} \mathrm{Co}\left(\mathrm{NO}_{3}\right)_{2}, 1.2765 \mathrm{~mol} \mathrm{~kg}^{-1}$ $\mathrm{NH}_{4} \mathrm{Cl}$ in $\mathrm{NH}_{4} \mathrm{NO}_{3} \cdot 2.61 \mathrm{H}_{2} \mathrm{O}$; $(3,4) 0.007301 \mathrm{~mol} \mathrm{~kg} \mathrm{~kg}^{-1}$ $\mathrm{Co}\left(\mathrm{NO}_{3}\right)_{2}, 1.1929 \mathrm{~mol} \mathrm{~kg} \mathrm{NH}_{4} \mathrm{Cl}$ in $\mathrm{NH}_{4} \mathrm{NO}_{3} \cdot \mathrm{CH}_{3}$ $\mathrm{CONH}_{2} \cdot 1.61 \mathrm{H}_{2} \mathrm{O}$; $(5,6) 0.001136 \mathrm{~mol} \mathrm{~kg}^{-1} \mathrm{Co}\left(\mathrm{NO}_{3}\right)_{2}$, $0.4993 \mathrm{~mol} \mathrm{~kg}^{-1} \mathrm{NH}_{4} \mathrm{Cl}$ in $\mathrm{NH}_{4} \mathrm{NO}_{3} \cdot 2 \cdot 61 \mathrm{CH}_{3} \mathrm{CONH}_{2}$. Temperature: $45(1,3,5)$ and $60{ }^{\circ} \mathrm{C}(2,4,6)$.

Addition of $\mathrm{NH}_{4} \mathrm{Cl}$ to cobalt(II) solutions in molten $\mathrm{NH}_{4} \mathrm{NO}_{3} \cdot 2.61 \mathrm{CH}_{3} \mathrm{CONH}_{2}$ (Fig. 3) and $\mathrm{NH}_{4} \mathrm{NO}_{3}$. $\mathrm{CH}_{3} \mathrm{CONH}_{2} \cdot 1.61 \mathrm{H}_{2} \mathrm{O}$ (Fig. 2) caused a significant shift of the absorption maximum toward lower energies and a large increase of the overall molar absorption coefficient with the increasing chloride concentration, indicating change from octahedral to tetrahedral co-ordination. In $\mathrm{NH}_{4} \mathrm{NO}_{3} \cdot 2.61 \mathrm{CH}_{3} \mathrm{CONH}_{2}$ (Fig. 3) an additional maximum appears at $664 \mathrm{~nm}$ as opposed to two maxima (at 627 and $665 \mathrm{~nm}$ ) in $\mathrm{NH}_{4} \mathrm{NO}_{3} \cdot \mathrm{CH}_{3} \mathrm{CONH}_{2} \cdot 1.61 \mathrm{H}_{2} \mathrm{O}$ (Fig. 2). In the $\mathrm{NH}_{4} \mathrm{NO}_{3} \cdot 2.61 \mathrm{H}_{2} \mathrm{O}$ melt the tetrahedral maximum with three peaks $(627,665$ and $688 \mathrm{~nm})$ appears only at very high chloride concentration (Fig. 1). The greater number of maxima in the latter two melts indicates simultaneous presence of more complexes in comparable concentrations and/or more similar values of successive stability constants. From a comparison of the overall molar absorption coefficient of chloride containing melts at approximately the same solute concentrations and $\left[\mathrm{Cl}^{-}\right] /\left[\mathrm{Co}^{2+}\right]$ ratios it is apparent that the cobalt(II) chloride complex formation tendency decreases with increase of the water content in the system $\mathrm{NH}_{4} \mathrm{NO}_{3}$ $\mathrm{CH}_{3} \mathrm{CONH}_{2}-\mathrm{H}_{2} \mathrm{O}$. 


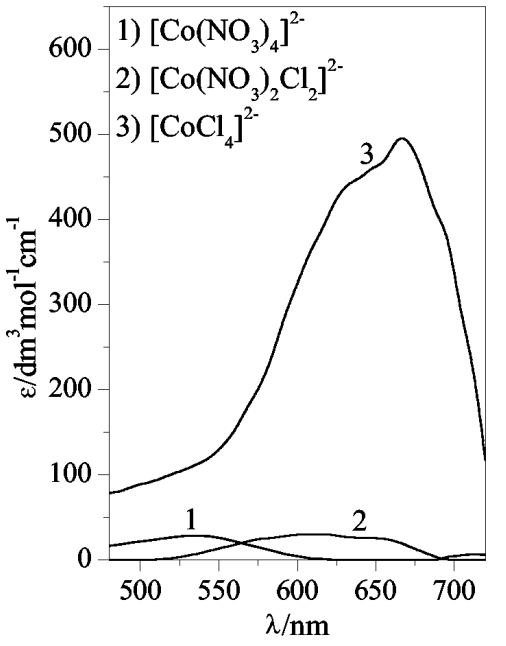

a

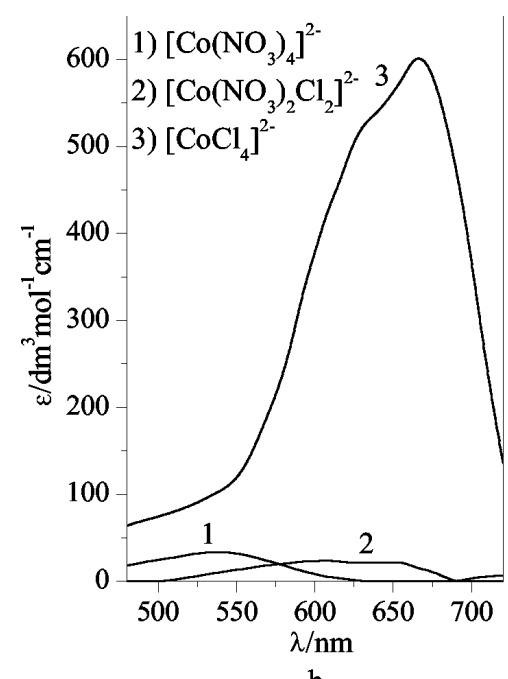

b
Fig. 5. Resolved species spectra of cobalt(II) chloride complexes at a) $45^{\circ} \mathrm{C}$ and b) $60{ }^{\circ} \mathrm{C}$.
An increase in temperature causes a large increase in the overall molar absorption coefficient of the chloride rich melts (Fig. 4), contrary to the normally expected behaviour of tetrahedral species. Again, the smallest temperature dependence exhibit the spectra in $\mathrm{NH}_{4} \mathrm{NO}_{3} \cdot 2.61 \mathrm{H}_{2} \mathrm{O}$. The cause of the increase in the absorption coefficient may be due to either the presence of lower octahedral or severely distorted octahedral mixed complexes with chloride and nitrate ions, or to higher stability of tetrahedral complexes at higher temperature [15].

\subsection{Stability Constants of the Complexes}

Changes in the absorption spectra with increased chloride concentration are ascribed to the stepwise complex formation. The complex formation equilibrium in a mixed ligand system

$$
\mathrm{M}+m \mathrm{~A}+n \mathrm{~B} \rightleftarrows \mathrm{MA}_{m} \mathrm{~B}_{n}
$$

can be defined by a set of stability constants

$$
\beta_{m n}=\left[\mathrm{MA}_{m} \mathrm{~B}_{n}\right] /[\mathrm{M}][\mathrm{A}]^{m}[\mathrm{~B}]^{n}
$$

On the basis of the cobalt(II) co-ordination by halide ions in other solvents we assumed that the complexes were mononuclear in cobalt(II), and that the maximum ligand co-ordination for cobalt(II) was 4.

For the computation of the stability constants $\beta_{m n}$ and species spectra $\varepsilon_{m n}(\lambda)$ the non-linear regression program STAR [18] was used. Part of the program is
Table 2. $\log \left(\beta_{m n} /\left(\mathrm{mol}^{-1} \mathrm{dm}^{3}\right)^{4}\right)$ for $\left[\mathrm{Co}\left(\mathrm{NO}_{3}\right)_{m} \mathrm{Cl}_{n}\right]^{2-m-n}$ in molten $\mathrm{NH}_{4} \mathrm{NO}_{3} \cdot 2.61 \mathrm{CH}_{3} \mathrm{CONH}_{2}$.

\begin{tabular}{cccc}
\hline$t /{ }^{\circ} \mathrm{C}$ & {$\left[\mathrm{Co}\left(\mathrm{NO}_{3}\right)_{4}\right]^{2-}$} & {$\left[\mathrm{Co}\left(\mathrm{NO}_{3}\right)_{2} \mathrm{Cl}_{2}\right]^{2-}$} & {$\left[\mathrm{CoCl}_{4}\right]^{2-}$} \\
\hline 45 & $2.42 \pm 0.05$ & $4.47 \pm 0.07$ & $5.83 \pm 0.06$ \\
60 & $2.50 \pm 0.08$ & $4.61 \pm 0.10$ & $6.14 \pm 0.08$ \\
\hline
\end{tabular}

Star/FA, which is used for the determination of absorbing species by factor analysis. On the basis of the absorption spectra, showing continual change with the chloride concentration and absence of an isosbestic point, one should expect overlapping of species spectra and formation of various complex species with chloride ligand including complexes with associated nitrate ions. For that reason, it is necessary to have a properly assumed chemical model including the number of complexes formed and good estimates of starting values of the parameters. We applied successfully the program STAR for the calculation of the stability constants of cobalt(II) chloride complexes in the system $\mathrm{NH}_{4} \mathrm{NO}_{3} \cdot 2.61 \mathrm{CH}_{3} \mathrm{CONH}_{2}$. In the case of the other two systems we did not achieve a convergence giving positive values of $\beta_{m n}$.

From a large number of trials to obtain the most relevant complexation model it was concluded that in the system $\mathrm{NH}_{4} \mathrm{NO}_{3} \cdot 2.61 \mathrm{CH}_{3} \mathrm{CONH}_{2}-\mathrm{Co}$ (II)- $\mathrm{Cl}^{-}$ the following species were formed: $\left[\mathrm{Co}\left(\mathrm{NO}_{3}\right)_{4}\right]^{2-}$, $\left[\mathrm{Co}\left(\mathrm{NO}_{3}\right)_{2} \mathrm{Cl}_{2}\right]^{2-}$ and $\left[\mathrm{CoCl}_{4}\right]^{2-}$. The overall stability constants of these complexes were calculated at $45{ }^{\circ} \mathrm{C}$ and $60{ }^{\circ} \mathrm{C}$. The obtained values are presented in Table 2.

The results support the assumption that mixed complexes are formed and that the stability of 


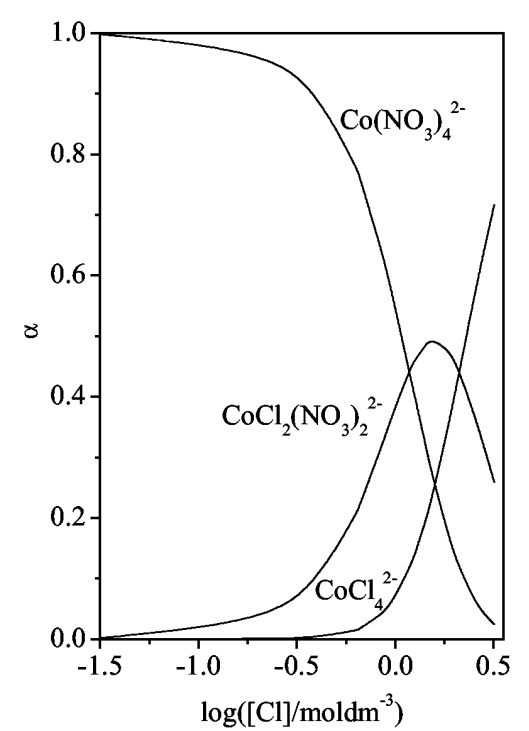

Fig. 6. The fraction $\alpha$ of $\mathrm{Co}(\mathrm{II})$ in different complexes $\left[\mathrm{Co}\left(\mathrm{NO}_{3}\right)_{m} \mathrm{Cl}_{n}\right]^{2-m-n}$ in $\mathrm{NH}_{4} \mathrm{NO}_{3} \cdot 2.61 \mathrm{CH}_{3} \mathrm{CONH}_{2}$ at $60{ }^{\circ} \mathrm{C}$.

the chloride complexes increases with temperature.

The resolved species spectra at 45 and $60{ }^{\circ} \mathrm{C}$, calculated using the values of the stability constants from Table 2 are displayed in Figure 5. The shape of the resolved spectrum of $\left[\mathrm{Co}\left(\mathrm{NO}_{3}\right)_{4}\right]^{2-}$ suggests, again, that this species in the melt of $\mathrm{NH}_{4} \mathrm{NO}_{3} \cdot 2.61 \mathrm{CH}_{3} \mathrm{CONH}_{2}$ most probably has an octahedral or dodecahedral co-ordination.

The position of the absorption maximum and the high value of $\varepsilon_{\max }$ of the resolved spectrum for $\left[\mathrm{CoCl}_{4}\right]^{2-}$ agree with those for tetrahedral $\left[\mathrm{CoCl}_{4}\right]^{2-}$ in concentrated aqueous $\mathrm{HCl}$ solutions [12] and

[1] G. Bombi, G. A. Sachetto, and C. Maccà, J. Electroanal. Chem. 225, 111 (1987).

[2] J. Savović, R. Nikolić, and D. Veselinović, Physical Chemistry 98, 4th Int. Conf. on Fundamental and Applied Aspects of Physical Chemistry, Belgrade, Yugoslavia, 1998, papers pp. $635-638$.

[3] J. Tripković, R. Nikolić, and D. H. Kerridge, J. Serb. Chem. Soc. 54, 527 (1989).

[4] S. B. Gadžurić, I. J. Zsigrai, and R. M. Nikolić, J. Mol. Liq. 83, 75 (1999).

[5] D. H. Kerridge, Chem. Soc. Rev. 17, 181 (1988).

[6] R. Nikolić, J. Tripković, and D. H. Kerridge, Thermochim. Acta 146, 353 (1989).

[7] R. Nikolić, G. Ristić, and M. Todorović, Sol. Energy Mater. Sol. Cells 28, 59 (1992). dimethyl formamide [19], indicating tetrahedral co-ordination. On the other hand, the molar absorption coefficient increases with temperature, a characteristic of octahedral species. Moreover, the resolved species spectrum for $\left[\mathrm{CoCl}_{4}\right]^{2-}$ in Fig. 5 agrees excellently with that for $\mathrm{CoCl}_{2}$ in molten $\mathrm{AlCl}_{3}$ reported by Øye and Gruen [20]. According to their model the $\mathrm{Co}^{2+}$ ion is octahedrally surrounded by six chloride ions. In view of this, it might also be assumed that the absorbing species in molten $\mathrm{NH}_{4} \mathrm{NO}_{3} \cdot 2.61 \mathrm{CH}_{3} \mathrm{CONH}_{2}$ is actually a severely distorted octahedron.

In case of the mixed complex $\left[\mathrm{Co}\left(\mathrm{NO}_{3}\right)_{2} \mathrm{Cl}_{2}\right]^{2-}$ no structural information can be gained from the corresponding resolved spectrum, the value of $\varepsilon$ being too uncertain for meaningful evaluation.

Figure 6 displays the fraction of cobalt(II) present in different complexes as a function of $\log \left(\left[\mathrm{Cl}^{-}\right] / \mathrm{mol}\right.$ $\mathrm{dm}^{-3}$ ). From Figs. 5 and 6 it is evident that the only species spectrum that can be obtained by direct measurement is that of $\left[\mathrm{Co}\left(\mathrm{NO}_{3}\right)_{4}\right]^{2-}$.

Although the stability constants of the complexes in melts of $\mathrm{NH}_{4} \mathrm{NO}_{3} \cdot 2.61 \mathrm{H}_{2} \mathrm{O}$ and $\mathrm{NH}_{4} \mathrm{NO}_{3} \cdot \mathrm{CH}_{3} \mathrm{CONH}_{2} \cdot 1.61 \mathrm{H}_{2} \mathrm{O}$ have not been calculated, a comparison of the spectra and the values of the overall molar absorption coefficient obtained at the same $\left[\mathrm{Cl}^{-}\right] /\left[\mathrm{Co}^{2+}\right]$ ratio suggests that with the replacement of water by acetamide increases the stability of cobalt chloride complexes.

\section{Acknowledgement}

This work was financially supported by the Ministry of Science and Environmental Protection of Republic of Serbia under contract no. 1399.

[8] M. Marinković, R. Nikolić, J. Savović, S. Gadžurić, and I. Zsigrai, Sol. Energy Mater. Sol. Cells 51, 401 (1998).

[9] R. Wallace and P. Bruins, J. Electrochem. Soc. 116, 21 (1967).

[10] G.E. McMains, A. N. Fletcher, and D.E. Bliss, Electrochim. Acta 31, 1971 (1986).

[11] J. Savović, R. Nikolić, and D. H. Kerridge, Fluid Phase Equilibria 118, 143 (1996).

[12] F. A. Cotton and G. Wilkinson, Advanced Inorganic Chemistry, 5th ed. John Wiley and Sons, New York 1988.

[13] I. V. Tananaev and B.F. Dzhurinskii, Dokl. Akad. Nauk. SSSR 134, 1374 (1960). 
[14] S. Hemmingsson and B. Holmberg, Inorg. Chem. 19, 2242 (1980).

[15] D. H. Kerridge, R. Nikolić, and D. Stojić, J. Chem. Soc. Dalton Trans., 1663 (1986).

[16] J. Dickinson and K. Johnson, J. Mol. Spectrosc. 33, 414 (1970).

[17] J. A. Duffi and M. D. Ingram, J. Am. Ceram. Soc. 51, 544 (1968).
[18] J. L. Beltrán, R. Codony, and M. D. Prat, Anal. Chim. Acta 276, 441 (1993).

[19] S. Buffagni and T.M. Dunn, J. Chem. Soc., 5105 (1961).

[20] H. A. Øye and D. M. Gruen, Inorg. Chem. 3, 836 (1964). 